\title{
Leadership and Followership in Post-Unipolar World: Towards Selective Global Leadership and a New Functionalism?
}

\author{
Shaun Breslin ${ }^{1}$ (D)
}

Received: 6 September 2017/ Accepted: 11 September 2017/Published online: 4 October 2017

(C) The Author(s) 2017. This article is an open access publication

\begin{abstract}
Despite a reduction in support for US global leadership (and an apparent reduction of desire to provide it), it remains unlikely that we will have a traditionally conceived of power transition where one power cedes global predominance to a challenger any time soon. Although power shifts really are occurring with more actors able and willing to provide leadership roles, this does not presage the onset of a multipolar order; at least as polar orders are typically understood. Rather, we see the transition to an order with multiple sites of authority that lacks the fixed and stable forms of alliances normally associated with polarity. David Mitrany's emphasis on the importance of functionalism might not provide a blueprint for the future, but does provide a way into thinking about non-polar forms of global governance, different and multiple sites of authority, and different forms of leadership within this global order. It also adds to the study of the capability and willingness of putative leaders, the importance of acceptance and followership in international relations.
\end{abstract}

Keywords Mitrany · Functionalism · Polarity global governance · Regionalism · Leadership

Shaun Breslin

shaun.breslin@warwick.ac.uk

1 Department of Politics and International Studies, University of Warwick, Coventry CV7 4AL, UK 


\section{Introduction}

In A Working Peace System, first published in $1943,{ }^{1}$ David Mitrany laid out a vision for a post-World War II global order where political differences should be put aside in the search for effective forms of transnational governance that would not repeat the errors of the past. Previous post-war settlements had resulted in the establishment of organizations from the Concert of Europe through the Hague Convention to the League of Nations that had abjectly failed to do what they were meant to do and prevent the slide into another war; each arguably more bloody than the previous one, and in the case of the two world wars, certainly more widespread. With the development of useable nuclear weapons getting ever closer in 1943, then there could be a real existential threat to mankind if the same pattern repeated itself in the future.

The key, he argued, was to avoid the creation of cohesive and stable groups or blocs of countries based on common ideological preferences and/or geopolitical strategic considerations. Such organizations not only created the basis for polarised rivalries that could lead to war, but were also in his view not very good governance institutions either. Coming into being through formal legal treaties and agreements, they would be by their very nature closed and rigid organizations that would simply be unable to deal with real world technical problems that instead required pragmatism and flexibility that spanned political divides. They would be:

rigid in framework, whether geographical or ideological; rigid in its constitution, which has to be formal and unchallenged; rigid in its general life, because of the limits and obstacles the constitution places in the path of fresh common action (Mitrany 1966, 155-6).

His alternative was to establish not a single form of governance, but multiple different forms instead. This could be done by first separating out different issue specific policy areas, and then by allowing the technicalities of each functional area to dictate how best to deal with their distinct and issue specific challenges. Who needed to be involved, the nature of cooperation and the way in which the organization functioned, and even the lifetime of each institutional arrangement should be defined by the agreement of technical specialists based on what was needed to deal with the specific shared problem. Given that each individual issue area would have its own set of discrete problems (and potential solutions) and affect different sets of actors, no two issues were likely to require the same form of organizational governance response. The result should be a wide range of very different arrangements "organized separately-each according to its nature, to the conditions under which it has to operate, and to the needs of the moment" (Mitrany 1966: 70).

In the event, of course, Mitrany's ideas did not transfer into reality, and the (bipolar) governance forms that evolved after 1945 went in exactly the direction that

\footnotetext{
1 There are different versions of what was originally a Chatham House pamphlet published in 1943. This paper has primarily used the more commonly consulted later version (Mitrany 1966) which includes other works on functionalism by Mitrany and an introduction by Hans Morgenthau.
} 
he feared would be ineffective, and would also fail to keep the peace. It also seems rather fanciful and naïve to propose a Mitranyesque depoliticised future, and there is no argument here that $A$ Working Peace System provides a realisable blueprint for global governance in the 21st century. Nevertheless, re-reading Mitrany and his focus on functional approaches (and solutions) to managing transnational issues remains a rewarding endeavour. In particular, it opens the door to thinking about the nature of leadership and alliances that free us from some of the conceptual constraints that can be imposed by dominant conceptions of both power transition and polarity.

The beginning of the end of US global dominance that emerged from the end of Cold War bipolarity has been identified (and subsequently rebuffed) on a number of occasions over the years. If, as Layne (2012) argues, "this time its for real" and the unipolar period is over, one possibility is a return to a new dichotomised global order. However, the more often predicted endpoint of the current and ongoing changing distribution of global power is a multipolar structure. Instinctively, this seems to make sense given the number of increasingly powerful actors (and not just states) that are competing with more established ones for influence and leadership, the current distribution of power capabilities amongst them, the willingness (of some) to lead, and the acceptance by others of (some) potential leaders' aims and ambitions. But while this suggests that the "multi" part of multipolarity is useful in pointing to the increasing number of increasing powerful (statist) actors that are emerging in the global order, the very same set of considerations (power capabilities and so on) suggest that "polarity" part of the concept is problematic if it implies the sort of stable and fixed alliances that are normally associated with polar global orders.

Rather than fixed bloc-type alliances, we seem to be witnessing the rise of multiple, overlapping and fluid constellations of power and interests that vary based on the specific (functional in Mitrany's words) issue at hand. And when it comes to leadership, rather than seeking a single global leader-either actual or putative-we instead need to focus on who has the capacity, desire and legitimacy to lead on any given policy area. We also need to think flexibly (following Mitrany's warning of rigidity) about which are the most effective sites and/or levels of governance, accepting that different leaders might simultaneously emerge in different hierarchies (for example, different regional leaders) and/or the relationship between regional and global leaders. Arguably even more important, it also requires us to focus on how and why others attach themselves to these putative leaders; or put another way, an essential component of studying leadership is to also study the sources of followership.

\section{Functionalism: Then and Now}

While Mitrany was writing in a different era, had limited practical policy influence, and might be seen to have been rather utopian in his thinking, his work helps us think about the nature of the current global order in three main ways. The first refers to the possibility that a form of institutional path dependency might obstruct the 
emergence of new forms of effective collective action. Here we return to what Mitrany (1965) called the "Federal Fallacy", and the problem of rigidity created by the formation of fixed organizations noted in the introduction; particularly (but not only) regional ones.

\subsection{Finding the Right Size and Fit}

Here, Mitrany was specifically interested in questions of leadership and legitimacy. The creation of these organizations, so his argument went, would lock in and perpetuate the interests and authority of the major powers that promoted them. This would not be palatable, he surmised, for those smaller less powerful states that would find their sovereignty fundamentally undermined by joining organisations as unequal partners. But while they might be wary of ceding sovereignty once and for all, they could be more prepared to deal with individual governance structures on a case-by-case basis (Mitrany 1966, 163). This would allow them to not be dominated by a hegemon, to selectively keep out of any arrangements that did not deem to be effective, or where the price of losing sovereignty was politically unacceptable at home, or where leadership in the organisation was not perceived to be legitimate (or a combination of all of these considerations). Moreover, while major powers would inevitably dominate a single federal organization, even small countries would find that there were some areas where they not only had expertise and authority, but were also perceived as having a comparative advantage by others. Thus, even the small and less powerful might be able to exert leadership in some issue areas (Mitrany 1966, 65).

More important, though, and the second way in which Mitrany's relevance persists, was the idea that these fixed forms simply did not always represent the most effective site of governance. Once the membership of an organization was set, and the way that it works was institutionalised, then it immediately lacked the flexibility that was necessary to deal with a range of different challenges. For example, a grouping established to deal with common security challenges might not encompass the right mix of states and other actors best suited to dealing with economic or environmental concerns. Or even considering economics as a single entity might be problematic - the range of actors and the location of expertise required to regulate shipping, for example, could be very different from that required to find effective solutions to problems in financial flows. This is not to say that a formal institution might not arise with its own constitution in the long term, or indeed that the aggregate combination of functional arrangements might combine to create some form of "constitutional" change (Mitrany 1966, 55). But if this was the case, then the new form should not be set in stone, but instead allow for flexibility and change; for countries joining, leaving and/or re-joining as the need arises. And members should also be prepared to close a specific institution down if it outlived its use or circumstances changed fundamentally (Mitrany 1966, 83). But the crucial thing for Mitrany, was that if such a broader constitutional form did emerge, then it should do so as a consequence of functional cooperation, and not become its originator. 
One conclusion of this way of thinking is that different types of issues require regulation and organisation at different levels. Some might need to be dealt with in true global settings, others at the regional level, and still others in ways that are not shaped by geography and instead link commonly affected partners together wherever they are. Another consequences is that even within a single given regional area, different forms of governance might be needed to find the most effective solution to the specific problem at hand. For example, as argued elsewhere (Elliott and Breslin 2011), the most effective environmental region often seems to be very different from the security region, or the region of trade and investment. And the final conclusion is that different actors can take the lead, and also be perceived by others as effective and legitimate leaders, depending on what it is that needs to be lead and governed; a conclusion that we will return to more than once in this paper. In summary:

Instead of keeping up the old and barren attempt to establish a formal and fixed division of sovereignty and power, a division which changing conditions continually puts out of joint, we would with a little insight and boldness distribute power in accordance with the practical requirements of every function and object (Mitrany 1966, 84).

\subsection{The Utility of Crises}

The third continuing relevance of Mitrany's promotion of functionalism revolves around his understanding of the positive role that crises can play in driving innovations that break down existing barriers to cooperation. The urgency of solving a crisis means that policy makers are likely to put aside ideology, principle and competition to simply do what has to be done to solve the problem at hand. The classic example was the way in which Roosevelt responded to the crisis of the Great Depression by simply doing what worked in each specific policy area and did not worry too much about what this meant in terms of consistency across policy areas. All that mattered was whether it worked or not (Mitrany 1966, 56).

The evolution of Chinese security policy over the years also provides a good example of how crises can bring about change. For example, the need to find common solutions to the transnational spread of SARS in 2003 and bird flu in 2006 turned the security focus away from just security defined as guns, bombs and bullets to new non traditional security challenges that were best met by multilateral cooperation and partnership and dialogue (Wang 2004). Similarly the Asian financial crisis played an important role in persuading policy makers across the region of the mutual benefits of working together in an ASEAN +3 framework to restore and guarantee regional financial stability. Indeed, we might suggest that economic crises have pushed China and Japan to seek for cooperation within a common regional framework, in contrast to the struggle to establish different preferences for regional organisation (including what the region itself should actually be) in more "normal" times.

Notably, the solution to these different crisis has led was not to seek for a single regional solution, but instead to identify different regional partners depending on the 
issue at hand. Thus while economic concerns pointed towards cooperation with ASEAN and Japan and South Korea, new security concerns have pointed instead towards:

the Shanghai Cooperation Organization, ASEAN Regional Forum, AsiaInfo meeting, the Asia-Pacific Security Council, the Northeast Asia Cooperation Dialogue and other multilateral security dialogue and cooperation processes (Fu 2003, 40).

This might not be a truly functionally defined set of governance institutions, but at the very least avoids the "federal fallacy" that Mitrany so feared.

\section{The Changing Nature of the Threat: The Changing Nature of World Order}

If the above discussion points to continuities between Mitrany's functionalism and the world today, there are of course also considerable differences between now and then. And these differences explain why the nature of power transition, the nature of world order, and the nature of leadership are also very different today than they were for much of the 20th century.

Mitrany argued that his apparent utopian call for the depoliticization of governance was not utopian at all, but based on historical evidence. He argued that there was ample evidence that international cooperation was most successful when international interactions had moved out of the control of foreign ministries and into the hands of technical specialists. But if it was utopian, it is not surprising. A Working Peace System was inspired by not just one crisis but a succession of them, and the urgency of establishing a foundation for peace on a continent that had more or less been characterised by its absence for most of the preceding century and a half (at least). Even when major states weren't actually at war, the fear of an impending conflict providing an overarching context for European international relations.

WWII was latest in a line of conflicts between the major European powers. Arguably starting from the 1870-1 Franco-Prussian War, technological advancements changed the nature of warfare (Wawro 2003, 51). ${ }^{2}$ Whilst the search for a lasting peace was of course important, there was a more immediate existential threat (Haftendorn 1991, 8) and the very real possibility that one or more European states might be destroyed and cease to exist (Goldgeier and McFaul 1992, 472). As Hans Morgenthau $(1966,7)$ noted in his introduction to the 1966 version of A Working Peace System, "the old national states of Europe barely survived the Second World War", and their chances of surviving a Third were even slimmer.

\footnotetext{
${ }^{2}$ As a result, the Conference also took the first steps in establishing what was justifiable conduct in war, which would later evolve into the Geneva Convention.
} 


\subsection{Cold War Bipolarity}

This existential threat combined with (and built on) ideological competition engendered strong perceptions of "us" and "them", which in turn helped shape the nature of the bloc-type bipolar order that emerged after WWII. To be sure, we need to raise a number of caveats to soften the understanding of a stark bifurcation between two opposing blocs with identical membership on all issue areas. First, the correlation of different spaces within each side of the divide was never fully complete. For example, some Western European countries came later than others to what became European Economic Community (EEC) during the Cold War, and some never joined. And the membership of the EEC never completely matched the European membership of the North Atlantic Treaty Organization (NATO).

Second, the example of NATO draws attention to different hierarchies within large alliances. For example, Franco-German leadership within the emerging European project existing under the overarching dominance of US leadership of the broader Western non-communist bloc (Hendriks and Morgan 2001). And notably, German economic leadership within the European economic project was not matched by leadership on security issues. Third, leadership was not autocratic, and there was room for countries to adopt individual initiatives and agenda. Again, Germany provides a good example here through the development of a form of rapprochement with Eastern Europe through the Ostpolitik strategy after 1969 (Griffith 1978).

Fourth, some countries did try to follow an independent path and not ally with either side-though even the different members of the Non Aligned Movement tended in practise to depend more on one or the other side of the divide for their economic and military support and interactions. Fourth, it was possible for countries to defect-if not to join the opposition then at least to try and tread an independent path, as was perhaps the case with Yugoslavia. Finally, China represents something of a special case. Having defected from its semi-attached membership of the Soviet bloc, ${ }^{3}$ China's self-proclaimed leadership of the Third World was accompanied by a willingness to exploit superpower rivalry between Washington and Moscow to establish some degree of security dependence on the USA.

But with these caveats in mind, we can suggest that the last time the World was characterised by a bipolar division, the fundamental nature of alliances were more or less fixed and set across issue areas. By and large, countries that came together stuck together and stayed together, and almost by definition, being attracted to one of the poles meant a repulsion of (and rejection by) the other alternative pole. If a country decided to ally itself for security reasons with the USA, it was highly unlikely (to say the least) that it would seek to ally itself with the Soviet Union on other issue areas.

\footnotetext{
3 Semi-attached because despite a reliance on Soviet economic and military support in the early days of the PRC, China never joined either the Warsaw Pact or COMECON.
} 


\subsection{The Power Transition From Unipolarity}

While it is always difficult to quantify different degrees or extents of powerperhaps even impossible - the highpoint of US unipolar power was arguably at some point near the turn of the millennium. After the end of the Cold War Japan's rise to global dominance had failed to materialise, strong state alternatives to neoliberal capitalism had been discredited in the form of a economic crises in Asia and elsewhere in 1997 and 1998, and the rise of China was yet to be seen as a real and significant challenge. Krauthammer $(2003,8) —$ one of the strongest proponents of US unipolarity - even saw the US response to September 11th as a sign of a new source of American power that "accelerate[d] the realignment of the current great powers, such as they are, behind the United States".

What Krauthammer saw as a source of strength ultimately turned into a cause of friction, and since then a variety of different forms of intervention in the Middle East and North Africa have done much to reduce the appeal and force of American preferences and authority within the global order, and done "irreparable damage" to the Responsibility to Protect principle and liberal international principles more generally (Adebajo 2016). It is fair to say that while there was more to the global financial crisis than just politics and policy in (and global leadership of) the United States, it has nevertheless contributed to a general feeling and understanding that en epochal change is imminent (if not already upon us). And decision by President Trump to take the US out of the Paris Climate Agreement has been seen by many as "the day that America's global leadership ended" (Reich 2017).

On the other side, whilst again being all but impossible to quantify, ${ }^{4}$ the rise of China and others has clearly changed the distribution of power and also arguable hierarchies of power. For example, there seems to be a fairly widely held view that previous asymmetries in power capabilities between Europe and China (or at least some parts of Europe) have flipped, with China now occupying the predominant position. It is not just that there has been a shift in material resources and capabilities, but that the European way of managing transnational challenges was found wanting; not just the way in which the Euro crisis came about in the first place, but in the difficulty of developing a common and effective response to it over a relatively long period (Jones, Kelemen and Meunier 2015). As a result, there is a broad consensus that as a result of the crisis, "the United States and China are the two most important states in the international system" (Foot and Walters 2011, 1).

So is the old unipolar order over? In thinking about change to the current global order, studies of the consequences of China's rise are often informed by previous power transitions and the search for similarities and differences that might explain whether the next transition can be a peaceful one or not. ${ }^{5}$ Moreover, considerations of power transformations are often based on the search for the moment where country A replaces country B. As Kupchan $(2012,182)$ reminds us, these "ordering moments" have typically historically been brought about through "post-war

\footnotetext{
${ }^{4}$ For a good collection that does a good job at trying to assess the extent of Chinese power from different perspectives in different areas, see Chung (2015).

5 See, for example, Chan (2007).
} 
settlements". Though there was no formal treaty to mark it, the end of bipolarity was also a post-war ordering moment of sorts.

Despite the various sources of a decline in support for US positions and preferences noted above, we are still missing a clear single ordering moment that marks the end of the old unipolar system and the creation of a new one. Moreover, the nature of the ongoing power transition means that we are unlikely to see a single ordering moment that is (hopefully at least) brought about by one side defeating the other; either militarily or in the way that the Cold War came to an end. There may indeed be some point in the future when China replaces the US as the global predominant power-perhaps even a unipolar one-and "rules the world" (Jacques 2009). But for the time being at least, the dominant concern is not so much what might happen in a new sinocentric order, but how the current order is incrementally being revised and reconfigured rather than replaced by something new. And rather than change in the global system being marked by a single overarching ordering moment, it might make more sense to look for a range of different ordering moments in different issue areas.

Furthermore, a weaker US is not the same thing as a weak US. Acharya (2014) persuasively argues that Washington is no longer able to freely impose its preferences on the world as it once did in the past. Nevertheless, if we think in terms of which country has "the largest single aggregation of power" (Haass 2008, 45), it is still difficult to look too far beyond the US. ${ }^{6}$ Changing the world and establishing a new order as the globally predominant power is one thing; pushing for change and trying to exert leadership in some areas) from a subordinate position is something else altogether.

\subsection{Bipolarity 2.0 ?}

One alternative to a unipolar order is the return to some form of bipolarity. And the idea that the US and China share some sort of special co-responsibility for providing global public goods-or perhaps more correctly, should develop some form of coleadership_does have some adherents (White 2012). While the original conception of an emerging G2 was largely rejected in China, subsequently the idea of a bipolar relationship of sorts was discussed as Chinese analysts considered what Xi Jinping's concept of a "new type of great power relations" might look like in practise. But even when the term bipolarity is explicitly used to refer to some form of new relationship and new world order, ${ }^{7}$ it does not sound like the previous bipolarity of the Cold War era; one where groups form as camps and blocs in fixed relationships in common opposition to the alternative pole.

This is partly because the existential threat that created the "Us" and "Them" of the Cold War is no longer the major driver of international alliances that it once was. To be sure, the threat of interstate (nuclear) war does establish the overarching

\footnotetext{
${ }^{6}$ And Nye (2010) is right to argue that the popular response to the global financial crisis might have exaggerated the extent and speed of the demise of US global power (and its replacement with Chinese power).

${ }^{7}$ For details of when it is, see Zeng and Breslin (2016).
} 
framework that largely conditions relations in other issue areas in some parts of the world; in South Asia for example. But in general, there is no overwhelming geostrategic security consideration that forces countries to choose between supporting one of two alternatives, and rejecting and opposing the alternative on all other issue areas.

Indeed, in many respects (and in some issue areas), there simply are not two polar opposites to choose from. China's embrace of the capitalist global economy might not have entailed the wholesale adoption of western neoliberalism. But it clearly hasn't create a diametrically different polar opposite form of Chinese economic activity from the type that dominates in other countries. And crucially, dealing with China does not create an exclusive relationship; there is certainly nothing about having economic relations with China that precludes also having economic relations with the US or anywhere else. Nor does building a security alliance with the US preclude having strong economic relationships with China, as is the case with a number of Southeast Asian nations. Whereas the nature of the Cold War resulted in exclusive relationships, the nature of the contemporary global capitalism encourages promiscuity.

\section{Multipolarity or Multiple Sites of Authority?}

While the focus on China as the most likely challenger to (or co-leader with) the US is entirely understandable, the distribution of power is more fragmented and uneven than a conception of a single power shift between two powers suggests. And while the rising powers share some traits and objectives, and five of them share an acronym and an institutionalised relationship, they do not constitute a single group or bloc. The paths to prominence of the rising powers are fundamentally different, they occupy different power positions, and draw on different combinations of sources of power (Kingah and Quiliconi 2016). Even those who share Chinese dissatisfaction with the existing order do so with different degrees of enthusiasm (Liu 2016), resulting in "intellectual disarray" (Kupchan 2012, 183) and the promotion of a variety of different governance preferences by different actors (Acharya 2014). The result is a rather complicated and competitive environmentperhaps even a messy one-where different preferences are articulated and promoted in different issue areas by an increasing number of actors.

So if unipolarity is coming to an end-or has already ended-and bipolarity seems overly simplistic, what of the idea of a turn towards multipolarity? If we think back to Mitrany's understanding of the best way of constructing international order, add to this a conception of the changing nature of the current global order, bring in the importance of legitimacy and followership, and a slightly different picture of changing configurations of power and influence in a post-unipolar global order begins to emerge. This understanding moves away from the connotation of fixed alliances that is - or at least was in the past-associated with polarity and instead points Mitrany's (1966) argument that different actors can have legitimacy and take leadership in different issue areas_-rather than one actor emerging as an accepted, legitimate and effective leader across all issue areas. 
So rather than power transferring from an old hegemon to a new one, or even to a group of different new poles in the global order, different sets of actors appear to have different levels of authority, and different abilities to attract supporters and allies, depending on the specific issue at hand. Rather than talk of multi polarity, it is more useful to think of multiple sites of authority where there are different nodes of power (Womack 2016), with different putative leaders competing for followership in the global order (Acharya 2014).

\subsection{Power Beyond the State}

A further reason for challenging (simplistic) assumptions about multipolarity is that it places too much emphasis on states-or states alone-as the potential sites of power (and thus polarity). And while states are clearly still central to the study of global power, they are not the only actors. For example, you don't have to think that the era of the nation state is dead as Ohmae did (1995) to nevertheless accept that non-state actors and "private authority" (Hall and Biersteker 2002) are important components of global power structures.

The most obvious example is the power of major corporations. If we return to China for an example, then it is clear that the way in which China's state elites chose to re-engage the global economy from the 1980s had a significant impact on global trade and investment flows. It was also used as evidence that "China is becoming a fourth pole in the international system" as way back as the early 1990s (Kristoff 1993, 62). But if this was an example of China's emerging power to change the world, it was a power that China could not simply wield on its own. It was also built on the investment and production decisions of major global companies, many of them headquartered in the US and Europe, and we might even argue was predicated in some ways on the purchasing habits and preferences of consumers in the west. If this is power, then the ability to change how, where, and at what cost global production occurs is at the very least shared between the (Chinese) state and major global companies. And of course, non-state economic actors like major hedge funds and major banks, have the ability to move money in and out of economies at the touch of a button in ways that have resulted in more than one major economic crisis (Korinek 2011).

Not only do major companies have considerable power to decide what type of economic activity takes place where, private actors are also key players in the evolution of governance forms in some areas. For example, private credit rating agencies have played a key role in economic governance for many years through their evaluation of the creditworthiness of national economies that can have huge implications for the nature of global financial flows. These evaluations can also "discipline" political elites intro following the sort of economic policies that will result in a good rating (Sinclair 2008). In Southeast Asia, private actors have been engaged by individual countries and by ASEAN as an organisation as partners in the search for effective forms of governance over policy arenas like air-borne pollution and haze, and the regional palm oil industry. This can include private actors actively lobbying for new forms of governance that serves their interests, rather than just being coopted by national or regional policy makers (Breslin and Nesadurai 2018). 
Moreover, there is more to the non-state sector than just companies and corporations. For example, thinking back to Mitrany's emphasis on the importance of technical specialist, students of governance and policy transfer have long emphasised the importance of transnational epistemic communities of

professionals with recognized expertise and competence in a particular domain and an authoritative claim to policy-relevant knowledge within that domain or issue area (Haas 1992, 3).

When it comes to thinking about global leadership, this suggests the importance of focussing on those "policy entrepreneurs" that play a key role in advocating and spreading ideas and norms relating to global regulation through these networks (Seabrooke and Wigan 2013). While this can take the form of the network representing the interests of one state or another-a means of transnationalising state power-it can also in some cases lead to the network establishing some form of identity and influence in its own right (Zeitlin 2015).

Engaging with policy networks inside and outside Europe has become an important way in which the European Union (EU) seeks to spread its governance norms and preferences. In some areas, this has created a leadership role of sorts for these European networks. For example, despite the fact that there is some suspicion in places that Europe tries to occupy a "moral high ground" when it comes to environmental issues, there is a wide acknowledgement that Europe has considerable capacity on environmentally related scientific issues. So here, any leadership (and legitimacy as a leader) that Europe has in the environmental realm is partly a result of the deliberate promotion of environmental strategies by the EU, but also partly a result of the expertise of European networks of scientific communities. ${ }^{8}$ This knowledge base-as articulated through the relationship between scientific and policy communities - might give the EU normative power and a leadership role on the environment, but it is power and leadership that derives in large part from the expertise and perceived legitimacy of non-state actors.

\subsection{Regions as Actors}

The above example of the EU and transnational networks highlight the role that regions can play as the originators and deliverers of preferred values and policies that have significance and influence beyond the regional sphere itself. Here, it is important to distinguish between regions as actors, and regions as a means through which states exercise power and promote their interests. Put another way, does a region have an interest and/or ability to act that is not simply a reflection of the interest of the dominant regional power?

To be sure, the "actorness" of different regions varies considerably, and not all have the ability or desire to be global actors, let alone leaders. Despite it's various ongoing problems, the EU remains the most obvious example of a region that has not only developed an identity as an independent global actor (van Langenhove 2012), but has also deliberately tried to externalise its governance preferences,

\footnotetext{
${ }^{8}$ On European environmental leadership, see Godzimirski (2015).
} 
though with different levels of success in different policy areas (Lavenex and Schimmelfennig 2009). In some areas (like the environment), it has been identified as exercising global leadership (Zito 2005). But the Association of Southeast Asian Nations (ASEAN) too has been identified as playing an independent leadership role beyond its borders (Kim 2012), albeit in the broader Asian region rather than globally. Other regional bodies have also in some ways been forced to become global actors through the way in which the EU has established interregional relations with them to discuss (and spread) European ideas over how best to provide transnational governance and global public goods (Soderbaum and van Langenhove 2006; Mattheis and Wunderlich 2017).

Even when regional organizations do not possess much actorness (let alone provide leadership) beyond their borders, they importantly remind us that power and leadership can be exercised at different levels or places. At times, and on some issues, the region might be perceived as a more effective or more legitimate (or both) site of governance than the global level. This is particularly so where the global level is seen as representing the interests and goals of "some" (which often simply means the West) rather than all. The decision to create the Asian Infrastructure Investment Bank might be a case in point here.

Referring back to Mitrany, a conceptual problem emerges around the very basic question of identifying exactly what the region is in which a leader does or should operate. Even within the same geographic space, there can be a number of different regional sites of governance, and therefore regional leadership. Using China as an example again, we can identify China's participation in (and in some cases leadership of) a wide range of different governance projects that have been described as being "regional". These include sub-regional projects in East and Southeast Asia (ASEAN-China Framework Agreement on Cooperation; Greater Mekong Subregion); still emerging financial trilateral cooperation between China, South Korea and Japan; collaboration alongside Korea and Japan with ASEAN (ASEAN Plus Three, the Chiang Mai Initiative); a separate exclusive bilateral relationship with ASEAN (The China-ASEAN Free Trade Area); a proposal for a Regional Comprehensive Economic Partnership that would expand the ASEAN plus three definition of region to include New Zealand, Australia and India; an even wider concept of region as Asia Pacific rather than just East Asia (APEC); an entirely different concept of region built on relations with former Soviet States to the north and (north)west (the Shanghai Cooperation Organization)' and a still evolving and unclear conception of territory and space built around the AIIB and/or the one belt one road initiatives. We could also further complicate matters by adding in China's participation in a non-geographic based organization in the shape of the BRICS (Brazil Russia India China South Africa).

What does all this mean for understandings of governance and leadership in a post-unipolar world? One very simple conclusion is the importance of reiterating the significance of multi-level governance perspectives on authority, organization and leadership. And perhaps more important, noting that it is often not a case of identifying if governance is provided at the global or regional level (or somewhere else), but that forms of governance can and do exist at different levels at the same time; sometimes in potentially conflicting ways, but also often in ways that 
complement and support each other. The promotion of regional environmental solutions by the UN might be one example of such complementarity (Elliott and Breslin 2011), and the role of the African Union in providing peacekeeping functions on the African continent might be another (Badmus 2015). So the region can be thought of as both a check on the creation of truly global forms of governance on some issues, and at the same time a building block towards it on other issues. Moreover, this understanding of different sites of governance means that different countries and actors can pursue and provide leadership on the same issue at different levels at the same time.

Another related conclusion is the need to identify leadership (or potential leadership) across a range of regions within any given geographic area rather than just focussing on one manifestation of region. Or put another way, a country that might be a regional leader on one issue might not even be conceived of as being part of the region at all when that region is defined by another set of issues and concerns.

And finally, defining what the region is-or perhaps more importantly, could or should be-can be a significant source of power and leadership itself. If we return to the above example of China's different regional identities and interactions, then Chinese preferences for an East Asia region (defined as ASEAN plus Three) might in part be because China can exert more influence in this region than in an IndoPacific region (that includes India and Australasia) favoured by others (Breslin 2007). Or to put it another way, the ability to lead or not is often shaped or constrained by who or what you are trying to lead.

\subsection{Followership in a Non-Polar World}

The third and final challenge to the understanding of polarity brings us back to assumptions about divergence in power capabilities and political alliances based on different issue/policy areas. The core argument at the heart of this paper is that bloctype polar alliances across issue areas are unlikely to be the dominating characteristic of global order in the foreseeable future. Of course some alliances may be more sustainable and across the board in nature than others. Japan's refusal to join the AIIB, for example, might be taken as a signal of a rather comprehensive and enduring Japan-US relationship across issue areas. But at the same time, the fact that the UK led a move by other traditional US allies to join the AIIB might tell another story about the weakening of previously more comprehensive sets of relationships. And the fact that those same western liberal actors have been much less keen to follow attempts to establish China's basic position and understanding as the basis for discussions on cybersecurity, for example (Sceats 2015), suggests that it is not a case of a new holistic bloc-type relationship replacing an old one.

If this understanding is correct, then clearly we need to try to identify the different positions that might provide the basis for leadership on any given issue area. The next step is to consider the extent to which they might be transferred from preferences to real leadership; to concrete proposals and initiatives (and/or organisations) that others are prepared to join. Here, it is useful to think of a tripartite distinction between willingness, capacity and acceptance-particularly, 
but not only, of those emerging powers that are widely thought to be challenging the nature of the existing global order (Kingah and Quiliconi 2016).

That powers (either rising or established) actually want to lead should not simply be assumed. For example, the US was reluctant to assume full global leadership in and after WWI, and at least part of the appeal of the Trump presidential message was the promise to reduce international contributions and place "America First". There also remains some doubt the extent to which China is prepared to take on all of the burdens and responsibilities that go with leadership (Shambaugh 2013). Despite a more active role in recent years, the promotion of "a new type of great power relations" by the Chinese leadership has at least something to do with establishing the limits to what China should be expected to do as a great power that is still also a developing country with many domestic problems still left to be resolved; problems that must take primacy over the provision of global public goods for others (Zeng and Breslin 2016).

Capability is important too. Other countries might have wanted to do something about the development finance gaps in Asia, but did not have had the resources that China had available to start up the AIIB. However, there is more to capability than just material resources. If we think in terms of ideational and normative capacities, we can ask if a country or any other actor has not just a set of new ideas, but also the means to articulate and disseminate them to others? And here in some ways capacity and acceptance should be seen as two sides of the same coin; unless a putative leader is prepared to force and bully its leadership on others, its capacity to lead is in large part dependent on others' desire to let it, and their willingness to align themselves to a leader.

As noted a number of years ago before the rise of China and the other BRICS were being seriously studied:

a leader-centered approach seriously distorts how we understand the nature of leadership in international politics. Focusing on the traits, interests, and capabilities of leaders and would-be challengers may tell us a great deal about which states are bound to be the most powerful in the international system at a particular historical conjuncture. But that approach tells us little about leadership, because it tells us little about the dynamics of followership-in other words, what drives followers to follow (Cooper, Higgott and Nossal 1991, 395).

Evidence suggests that the inclination to follow often appears to be dependent on whether the leading power incorporates elements of the putative follower's interests and positions into its own agenda (Schirm 2010). So if effective leadership (other than through coercion and force) is dependent on followership, this perhaps suggests the need for a stronger focus in the future on the followers than much of the recent scholarship on the role and goals of rising powers has found space to encompass. 


\section{Conclusion}

With the benefit of hindsight, the current apparent turn to a fragmented non-polar world might only be a temporary phenomenon. After all, what appeared to be an inevitable Japanese rise to some form of global economic leadership in the mid to late 1980s did not turn to be inevitable at all, and all of the current crop of rising powers have domestic governance challenges to deal with that could result in a reduction in their willingness and capability to provide forms of leadership in the future. Or they might do things as they continue to rise that reduce their legitimacy as a leader in the eyes of putative followers. Or alternatively, we might simply be in an interregnum before the creation of a new polar world order (of whatever type) under new leadership.

For the time being, though, the argument here is that we will continue to live in an era characterized by ongoing and complex negotiations leading to the reformulation of alliances and relationships in a global order where an increasingly weak and potentially less globally inclined US nevertheless remains the predominant global power. And while Mitrany's preferences for a functional world do not provide us with a simple and clear roadmap of how to construct such a functional world, or what the subsequent global order might look at, his emphasis on functionalism does provide us with a useful way of thinking about alternative non-polar forms of global organization; including forms that are not uniquely the preserve of states and state actors as participants and potential leaders (in some, if not all, issue areas).

A functionally inclined world with issue based alliances rather than blocs and camps provides an opportunity for a variety of actors to promote themselves as leaders; not necessarily global leaders per se, but leaders on a specific issue area. It also allows for them to gain followership on some domains from those who might find themselves in diametrically opposite alliances on other issue areas. When combined with an understanding of governance beyond-or is that beneath- the global level, then the consequence is a messy and fragmented set of different (sometimes, but not always) overlapping governance and leadership forms and agendas. And it is a world that arguably places more of an emphasis on the preferences of putative followers than the dominant focus on the preference of potential challengers and leaders often allows for.

Despite the emphasis here on discrete and separate policy areas, it is important to accept that each policy domain is not hermetically sealed from what happens in others. In particular, the acceptance by others of a leader in one area can be heavily influenced by perceptions of how that putative leader has acted in other functional areas (either as a leader or not); particularly if the rising challenger power emerges from outside the heartlands of the liberal Western world. In terms of the way in which some governance initiatives are perceived at least (and ultimately not surprisingly), the political and ideological differences that Mitrany thought should not be a consideration when developing effective forms of governance really do still have a key role to play today. This makes the task of building even selective leadership in some policy areas more difficult than is the case for established (liberal) powers whose fundamental commitment to existing order is less likely to be undermined by something that they do (or don't do) in one policy arena. 
Open Access This article is distributed under the terms of the Creative Commons Attribution 4.0 International License (http://creativecommons.org/licenses/by/4.0/), which permits unrestricted use, distribution, and reproduction in any medium, provided you give appropriate credit to the original author(s) and the source, provide a link to the Creative Commons license, and indicate if changes were made.

\section{References}

Acharya, Amitav. 2014. The end of American World Order. Oxford: Polity.

Adebajo, Adekeye. 2016. The revolt against the West: intervention and sovereignty. Third World Quarterly 37 (7): 1187-1202.

Badmus, Isiaka. 2015. The African Union's role in peacekeeping: Building on lessons learned from security operations. Basingstoke: Palgrave.

Breslin, Shaun. 2007. Supplying Demand or Demanding Supply? An Alternative Look at the Forces Driving East Asian Community Building. Stanley Foundation Policy Analysis Brief. http://www. stanleyfoundation.org/resources.cfm?id=268. Accessed 1 December 2007.

Breslin, Shaun, and Nesadurai, Helen. 2018. In Who Governs and How? Non-State Actors and Transnational Governance in Southeast Asia, ed. Special issue of Journal of Contemporary Asia, forthcoming.

Chan, Steve. 2007. China, the US and Power-Transition Theory: A Critique. Abingdon: Routledge.

Chung, Jae Ho (ed.). 2015. Assessing Chinese Power. Basingstoke: Palgrave.

Cooper, Andrew, Richard Higgott, and Kim Nossal. 1991. Bound to Follow? Leadership and Followership in the Gulf Conflict. Political Science Quarterly 106 (3): 391-410.

Elliott, Lorraine, and Shaun Breslin. 2011. Researching Comparative Regional Environmental Governance: Causes, Cases and Consequences. In Comparative Environmental Regionalism, ed. Lorraine Elliott, and Shaun Breslin, 1-18. London: Routledge.

Foot, Rosemary, and Andrew Walter. 2011. China, the United States and global order. Cambridge: Cambridge University Press.

Fu, Yong. 2003. Shi lun lengzhan hou de feichuantong anquan wenti [An Examination of post cold war non traditional security issues]. Shehui Kexue [Social Science] 10: 33-40.

Godzimirski, Jakub (ed.). 2015. EU Leadership in Energy and Environmental Governance. Basingstoke: Palgrave.

Goldgeier, James, and Michael McFaul. 1992. A Tale of Two Worlds: Core and Periphery in the PostCold War Era. International Organization 46 (2): 467-491.

Griffith, William. 1978. The Ostpolitik of the Federal Republic of Germany. Cambridge: MIT Press.

Haas, Peter. 1992. Introduction: Epistemic Communities and International Policy Coordination. International Organization 46 (1): 1-35.

Haass, Richard. 2008. The age of nonpolarity: What will follow US dominance. Foreign Affairs 87 (3): 44-56.

Haftendorn, Helga. 1991. The Security Puzzle: Theory-building and Discipline-building in international Security. International Studies Quarterly 35 (1): 3-17.

Hall, Rodney, and Thomas Biersteker (eds.). 2002. The Emergence of Private Authority in Global Governance. Cambridge: Cambridge University Press.

Hendriks, Gisela, and Annette Morgan. 2001. The Franco-German axis in European integration. Cheltenham: Edward Elgar.

Jacques, Martin. 2009. When China rules the World: The rise of the Middle Kingdom and the end of the Western world. London: Penguin.

Jones, Erik, Daniel Kelemen, and Sophie Meunier. 2015. Failing Forward? The Euro Crisis and the Incomplete Nature of European Integration. Comparative Political Studies 49 (7): 1010-1034.

Kim, Min-hyung. 2012. Why Does A Small Power Lead? ASEAN Leadership in Asia-Pacific Regionalism. Pacific Focus 27 (1): 111-134.

Kingah, Stephan, and Cintia Quiliconi (eds.). 2016. Global and regional leadership of BRICS Countries. New York: Springer.

Korinek, Anton. 2011. Hot Money and Serial Financial Crises. IMF Review 59 (2): 306-339.

Krauthammer, Charles. 2003. The unipolar moment revisited. The National Interest 79: 5-18. (Winter).

Kristoff, Nicholas. 1993. The Rise of China. Foreign Affairs 72 (5): 59-74. 
Kupchan, Charles. 2012. No one's world: The West, the rising rest, and the coming global turn. New York: Oxford University Press.

Lavenex, Sandra, and Frank Schimmelfennig. 2009. EU rules beyond EU borders: theorizing external governance in European politics. Journal of European Public Policy 16 (6): 791-812.

Layne, Christopher. 2012. This time its for real: The end of unipolarity and the Pax American. International Studies Quarterly 58 (1): 203-213.

Liu, Ming. 2016. BRICS development: a long way to a powerful economic club and new international organization. The Pacific Review 23 (3): 443-453.

Mattheis, Frank, and Uwe Wunderlich. 2017. Regional actorness and interregional relations: ASEAN, the EU and Mercosur. Journal of European Integration 2017: 1. doi:10.1080/07036337.2017.1333503. (Accessed 7 August).

Mitrany, David. 1965. The Prospect of Integration: Federal or Functional. Journal of Common Market Studies 4 (2): 119-149.

Mitrany, David. 1966. A Working peace system. Chicago: Quadrangle.

Morgenthau, Hans. 1966. Introduction. A Working Peace System, David Mitrany, 7-11. Chicago: Quadrangle.

Nye, Joseph. 2010. American and Chinese Power after the Financial Crisis. The Washington Quarterly 33 (4): 143-153.

Ohmae, Kenichi. 1995. The End of the Nation-State: the Rise of Regional Economies. New York: Simon and Schuster.

Reich, Simon. 2017. The end of America's global leadership. The Conversation. https://theconversation. com/the-end-of-americas-global-leadership-78736. Accessed 5 June 2017.

Sceats, Sonja. 2015. China's cyber diplomacy: a taste of law to come. The Diplomat. http://thediplomat. com/2015/01/chinas-cyber-diplomacy-a-taste-of-law-to-come. Accessed 16 January 2015.

Schirm, Stefan. 2010. Leaders in need of followers: Emerging powers in global governance. European Journal of International Relations 16 (2): 197-221.

Seabrooke, Leonard, and Wigan, Duncan. 2013. Emergent Entrepreneurs in Transnational Advocacy Networks: Professional Mobilization in the Fight for Global Tax Justice. GREEN Working Paper No. 41, Centre for the Study of Globalisation and Regionalisation, University of Warwick. http:// www2.warwick.ac.uk/fac/soc/pais/research/researchcentres/csgr/green/papers/workingpapers/no._ 41_seabrooke_and_wigan.pdf. Accessed 5 December 2013.

Shambaugh, David. 2013. China Goes Global: The partial power. Oxford: Oxford University Press.

Sinclair, Timothy. 2008. The New Masters of Capital: American Bond Rating Agencies and the Politics of Creditworthiness. Ithaca: Cornell University Press.

Soderbaum, Frederick, and Luk van Langenhove. 2006. The EU as a Global Player: The Politics of Interregionalism. London: Routledge.

van Langenhove, Luk. 2012. The EU as a Global/Regional Actor in Security and Peace. Bruges: UNU CRIS. https://collections.unu.edu/eserv/UNU:1697/Final_Integrative_Report3.pdf Accessed 13 March 2013.

Wang, Yizhou. 2004. Zhongguo yu feichuantong anquan [China and nontraditional security]. Guoji Jingji Pinglun (International Economic Review) 6: 32-35.

Wawro, Geoffrey. 2003. The Franco-Prussian War: The German conquest of France in 1870-1871. Cambridge: Cambridge University Press.

White, Hugh. 2012. The China choice: Why the US should share power. Oxford: Oxford University Press. Womack, Brantly. 2016. Asymmetry and international relationships. New York: Cambridge University Press.

Zeitlin, Jonathan (ed.). 2015. Extending Experimentalist Governance? The European Union and Transnational Regulation. Oxford: Oxford University Press.

Zeng, Jinghan, and Shaun Breslin. 2016. China's "New Type of Great Power Relations": A G2 with Chinese Characteristics? International Affairs 92 (4): 773-794.

Zito, Anthony. 2005. The European Union as an environmental leader in a global environment. Globalizations 2 (3): 363-375.

Shaun Breslin is Professor of Politics and International Studies at the University of Warwick. He is also co-editor of The Pacific Review, and a Fellow of the UK Academy of Social Sciences. His research focuses on the political economy and international relations of contemporary China, with a side interest in comparative studies of regional integration. 